\title{
Anti-L-NGFR and -CD34 Monoclonal Antibodies Identify Multipotent Mesenchymal Stem Cells in Human Adipose Tissue
}

\author{
Nadia Quirici, ${ }^{1}$ Cinzia Scavullo, ${ }^{1, \star}$ Laura de Girolamo, ${ }^{2, \star}$ Silvia Lopa, ${ }^{3}$ Elena Arrigoni, ${ }^{3}$ \\ Giorgio Lambertenghi Deliliers, ${ }^{4, *}$ and Anna T. Brini ${ }^{3, *}$
}

Stem cells hold great promise in tissue engineering for repairing tissues damaged by disease or injury. Mesenchymal stem cells (MSCs) are multipotent cells able to proliferate and differentiate into multiple mesodermal tissues such as bone, cartilage, muscle, tendon, and fat. We have previously reported that the low-affinity nerve growth factor receptor (L-NGFR or CD271) defines a subset of cells with high proliferative, clonogenic, and multipotential differentiation ability in adult bone marrow (BM). It has been recently shown that adipose tissue is an alternative source of adult multipotent stem cells and human adipose-derived stem cells, selected by plastic adherence (PA hASCs), have been extensively characterized for their functional potentials in vitro. In this study, immunoselected L-NGFR ${ }^{+}$and CD $34^{+}$subpopulations have been analyzed and compared with the PA hASCs. Phenotypic profile of freshly purified subpopulations showed an enrichment in the expression of some stem cell markers; indeed, a great percentage of L-NGFR ${ }^{+}$cells co-expressed CD34 and CD117 antigens, whereas the endothelial-committed progenitor markers KDR and P1H12 were mainly expressed on CD34 ${ }^{+}$cells. Differently from PA hASCs, the immunoseparated fractions showed high increments in cell proliferation, and the fibroblast colony-forming activity (CFU-F) was maintained throughout the time of culture. Furthermore, the immunoselected populations showed a greater differentiative potential toward adipocytes, osteoblasts, and chondrocytelike cells, compared to PA hASCs. Our data suggest that both $\mathrm{CD}^{+} 4^{+}$and L-NGFR ${ }^{+}$hASCs can be considered alternative candidates for tissue engineering and regenerative medicine applications.

\section{Introduction}

TN THE RECENT YEARS, the emerging field of cell-based therlapies for repair and regeneration of damaged tissues has been focusing on the identification of the ideal source of stem cells, which combines the ability of multipotential differentiation and the accessibility in large amounts under a minimally invasive procedure, not complicated by immunological rejection concerns and ethical controversies.

Adult mesenchymal stem cells (MSCs) are a population of multipotent cells able to proliferate and differentiate into multiple mesodermal tissues. MSCs have been initially identified in bone marrow (BM) [1], but have been subsequently isolated from many other tissues [2-10]. Among them, human MSCs derived from adipose tissue (hASCs) show stem cell key features such as the ability to form fibroblast-like colonies (CFU-F), the expression of several common cell surface antigens, the capacity of extensive proliferation, and the potential to differentiate in vitro and in vivo into multiple lineages of mesodermal origin, and also to transdifferentiate into neurogenic and hepatic lineages [4,11-21]. Similarly to BM-derived MSCs (BM MSCs), hASCs are able to suppress immunoreactivity, suggesting a possible overcoming of histocompatibility limitations in allogeneic transplantation $[22,23]$; furthermore, they are easily accessible in large amounts by liposuction $[4,24,25]$. Several studies have demonstrated the efficacy of these cells in clinical applications; in particular, the cell-assisted lipotransfer technique has been successfully used for the treatment of facial lipoatrophy

${ }^{1}$ Fondazione Matarelli, Department of Medical Pharmacology, Università degli Studi di Milano; ${ }^{2}$ IRCCS Istituto Ortopedico Galeazzi ${ }^{3}$ Department of Medical Pharmacology, Università degli Studi di Milano; and ${ }^{4}$ UO Ematologia-CTMO, Fondazione IRCCS Ospedale Maggiore Policlinico, Mangiagalli e Regina Elena, Università degli Studi di Milano, Milan, Italy.

*These authors contributed equally to this work. 
and breast augmentation [26,27] and a clinical trial is actually in progress to evaluate the efficacy of the reimplantation of autologous hASCs purified through the Celution ${ }^{\circledR}$ system (Cytori Inc., San Diego, CA) for breast reconstruction. Moreover, 2 clinical trials (Phase I and Phase II, respectively) were recently performed using in vitro-expanded hASCs for the treatment of perianal fistula [28,29], with satisfactory results.

These cells have been extensively characterized for their functional potential; however, the heterogeneity of the starting cell population and the variability in stem cell recovery among different donors and subcutaneous adipose tissue depots [4,30-33] cause some difficulties to reproduce and compare the results, underlining the need of specific markers able to identify primitive and multipotent adipose-derived stem cells.

We have previously shown that monoclonal antibodies (MoAbs) to the low-affinity nerve growth factor receptor (L-NGFR or CD271) stain primitive MSCs with high specificity and purity in adult BM, defining a subset of cells with higher clonogenic efficiency, proliferative and differentiative potential in comparison to the whole MSCs population [34]. Furthermore, some authors have highlighted the presence of CD $34^{+}$cells in the freshly isolated stromal vascular fraction (SVF) from human adipose tissue [18,19,35,36]. Isolation of $\mathrm{CD} 34^{+} / \mathrm{CD} 31^{-}$cells has revealed that this population differentiated in vitro into endothelial cells and promoted in vivo angiogenesis, participating in the revascularization of ischemic hind limbs of nude mice [18].

In this study, we compare the whole hASCs population, purified by plastic adherence (PA hASCs), with 2 immunoselected subpopulations (L-NGFR ${ }^{+}$and $\mathrm{CD} 34^{+} \mathrm{hASC}$ ), evaluating their phenotypic stem cell profile, their proliferative and clonogenic potential, and their ability to differentiate toward adipocytes, osteoblasts, and chondrocyte-like cells.

Our results show that $\mathrm{L}-N G F R^{+}$and $\mathrm{CD}^{+} 4^{+}$hASCs are 2 distinct purified populations, with a higher clonogenic and differentiative ability compared to the PA unselected population.

\section{Materials and Methods}

\section{hASCs isolation}

Subcutaneous adipose tissue was collected from 12 female patients (mean age: $40.4 \pm 6.6$ years, BMI $<30$, without any pathological obesity) who underwent aesthetic liposuction of the abdomen (3-4 mm diameter hollow blunt cannula connected to the syringe) at the Plastic and Reconstructive Surgery Unit of the Galeazzi Orthopaedic Institute. All the procedures were approved by the internal IRB and were performed by a senior plastic surgeon of the institute; all patients gave their consent for the research use of the waste tissue deriving from surgical interventions.

Adipose stem cells were isolated as previously described [11]. In brief, the raw lipoaspirates (50-100 mL) were washed at least 3 times with phosphate-buffered saline (PBS) and the matrix was digested with $0.075 \%$ type I collagenase (Worthington, Lakewood, $\mathrm{NJ}$ ) at $37^{\circ} \mathrm{C}$ with continuous agitation for $30 \mathrm{~min}$. The SVF was centrifuged $(1,200 \mathrm{~g}, 10 \mathrm{~min})$ and filtered through a sterile medication lint; the collected cells were centrifuged, resuspended in control medium consisting of DMEM (Sigma-Aldrich, Milan, Italy) supplemented with 10\% FBS (fetal bovine serum; Lonza, Milan, Italy), $50 \mathrm{U} / \mathrm{mL}$ penicillin (Sigma-Aldrich), $50 \mu \mathrm{g} / \mathrm{mL}$ streptomycin (SigmaAldrich), and $2 \mathrm{mM}$ L-glutamine (Sigma-Aldrich) and then counted. Cells were either plated in control medium at a density of $10^{5}$ cells $/ \mathrm{cm}^{2}$ to select the progenitor cells by plastic adherence (PA hASCs) or immunoselected by L-NGFR and CD34 MoAbs as described below.

\section{Positive selection of $\mathrm{CD} 34^{+}$and $\mathrm{L}^{-N G F R^{+}}$hASCs}

Positive selection of $\mathrm{CD}_{3} 4^{+}$and L-NGFR ${ }^{+}$cells was performed using the Direct CD34 Progenitor Cell Isolation Kit and the CD271 Microbead Kit, respectively (Miltenyi Biotech, Calderara di Reno, Italy), according to the manufacturers' instructions. Cells were then counted and assessed for viability; their purity was determined by flow cytometry.

\section{Flow cytometry analysis}

To analyze the expression of specific surface markers, $2 \times$ $10^{5} \mathrm{hASC}$ were incubated with the following anti-human primary MoAbs: CD34-FITC (8G12), CD117-APC (YB5B8), CD45PerCP (2D1) (Becton Dickinson, Milan, Italy), AC133/2-PE and AC133-APC (293C3) (CD133) (Miltenyi Biotech), CD146FITC and -PE (P1H12; Chemicon International Inc., Temecula, CA), CD105-FITC (SN6; Serotec Inc., Raleigh, NC), NGFR-PE (C40-1457; BD PharMingen, Milan, Italy), KDR-APC (89106; R\&D Systems, Minneapolis, MN) and glycophorin A-FITC (Immunotech SAS, Marseille, France). Samples were then evaluated by FACSCanto II Instrument and Diva software (Becton Dickinson).

\section{hASCs cultures}

After the isolation, $\mathrm{PA}, \mathrm{CD}^{+} 4^{+}$, and $\mathrm{L}_{-\mathrm{NGFR}^{+}}$hASCs were cultured in control medium at $37^{\circ} \mathrm{C}$ in a humidified atmosphere $\left(5 \% \mathrm{CO}_{2}\right)$, with weekly refeeds. Cells were grown until $90 \%$ confluency, detached by $0.25 \%$ trypsin $/ 1$ mM EDTA (Sigma-Aldrich) for $5 \mathrm{~min}$ at $37^{\circ} \mathrm{C}$, counted to assess their proliferation, and tested for CFU-F efficiency and differentiation potential; $10 \%$ of the collected cells were re-expanded.

\section{MSCs progenitor assays}

Colony-forming units-fibroblast (CFU-F) assay. The clonogenic ability of PA, CD $34^{+}$, and L-NGFR ${ }^{+}$hASCs fractions was determined by a low-density CFU-F assay performed at different passages in culture [37]. The cells from the 3 populations were resuspended in control medium supplemented with $20 \%$ FBS and seeded in 6-well plates at different cellular density: 1-3-6-12-24-48 cells $/ \mathrm{cm}^{2}$. After 5 days of culture, half of the medium was removed and replaced by fresh medium; after 9 days, the wells were rinsed with PBS, fixed with methanol, and stained with Crystal Violet (Sigma-Aldrich). The colonies consisting of $\geq 50$ cells were counted and the frequency of colonies was expressed on 1 $\times 10^{3}$ plated cells.

Hematopoietic progenitor assays. The colony-forming unit-granulocyte/macrophage (CFU-GM) and burst-forming unit-erythroblast (BFU-E) assays were carried out by plating $1 \times 10^{5} \mathrm{CD} 4^{+}$cells in a methylcellulose culture 
medium (MethoCult GF H4434; StemCell Technologies Inc., Vancouver, Canada). Triplicate dishes were incubated at $37^{\circ} \mathrm{C}$ and $5 \% \mathrm{CO}_{2}$ in a fully humidified atmosphere. After 14 days of culture, aggregates formed by $\geq 50$ cells were scored as colonies and counted.

\section{Functional assays}

Adipogenic differentiation. In order to induce adipogenic differentiation, $5 \times 10^{5} \mathrm{hASC}$ from the different fractions were cultured in hMSC Mesenchymal Stem Cell Adipogenic Differentiation Medium (Lonza) in T-25 flasks, with weekly refeeds. After 21 days of culture, the cells were fixed in $10 \%$ formalin for $10 \mathrm{~min}$ and stained with fresh Oil Red-O solution (Sigma-Aldrich). Oil Red-O was extracted from the fixed samples incubating for $10 \mathrm{~min}$ with $100 \%$ isopropanol. Absorbance was read at $490 \mathrm{~nm}$ with Wallac Victor II plate reader.

Osteogenic differentiation. In order to differentiate cells toward the osteogenic lineage, $2.5 \times 10^{5}$ hASCs from the 3 populations were plated in T-25 flasks and cultured in hMSC Mesenchymal Stem Cell Osteogenic Differentiation Medium (Lonza), with weekly refeeds [38]. After 21 days, cells were washed with PBS, fixed with ice-cold ethanol $70 \%$ for $1 \mathrm{~h}$, and stained with Alizarin Red S (40 mM, pH 4.1, Sigma-Aldrich) for $10 \mathrm{~min}$ in order to detect calcium deposition [39]. Alizarin Red S was extracted incubating samples for $30 \mathrm{~min}$ with $10 \% \mathrm{w} / \mathrm{v}$ cetylpyridinium chloride in $0.1 \mathrm{M}$ phosphate buffer ( $\mathrm{pH}$ 7.0) [40]. Absorbance was read at 550 nm with Wallac Victor II plate reader.

Chondrogenic differentiation. Chondrogenic differentiation was induced in pellet culture conditions: $5 \times 10^{5} \mathrm{hASCs}$ from the different fractions were centrifuged $(500 g, 5 \mathrm{~min})$ in a $15-\mathrm{mL}$ centrifuge tube, the pellets were resuspended either in control or in chondrogenic medium consisting of DMEM supplemented with 1\% FBS (Lonza), $50 \mathrm{U} / \mathrm{mL}$ penicillin, $50 \mu \mathrm{g} / \mathrm{mL}$ streptomycin, and $2 \mathrm{mM}$ L-glutamine, $1 \mathrm{mM}$ sodium pyruvate (Sigma-Aldrich), $0.15 \mathrm{mM}$ L-ascorbic acid2-phosphate (Sigma-Aldrich), 1× ITS (Sigma-Aldrich), 0.1 $\mu \mathrm{M}$ dexamethasone (Sigma-Aldrich), and $10 \mathrm{ng} / \mathrm{mL}$ TGF- $\beta 1$ (Biosource-Invitrogen, Camarillo, CA) and then centrifuged again $(500 \mathrm{~g}, 5 \mathrm{~min})$; medium was changed twice a week. After 21 days, micromasses were digested overnight at $56^{\circ} \mathrm{C}$ by proteinase $\mathrm{K}\left(50 \mu \mathrm{g} / \mathrm{mL}\right.$ in $100 \mathrm{mM} \mathrm{K}_{2} \mathrm{HPO}_{4}$, $\mathrm{pH}$ 8.0, final digestion volume $100 \mu \mathrm{L}$; Sigma-Aldrich). Sulfated glycosaminoglycans (GAGs) were then quantified according to a modified version of the dimethylmethylene blue (DMMB; Sigma-Aldrich) assay [41]. Absorbance was read at $655 \mathrm{~nm}$ and the GAGs content, expressed as $\mu \mathrm{g}$ GAGs/micromass, was determined using bovine trachea chondroitin-4-sulfate (Sigma-Aldrich) as standard.

GAGs content of each sample was normalized with respect to DNA measured by Hoechst 33258 fluorescence assay (355 $\mathrm{nm}$ excitation-460 $\mathrm{nm}$ emission, Wallac Victor II plate reader) using salmon sperm DNA as standard.

\section{Statistical analysis}

The Student's $t$-test for paired data was used to test the probability of significant differences between paired samples for variables with normal distribution.
Differentiation increments were evaluated by one-sample Student's $t$-test.

Differences were considered statistically significant at $P<0.05$.

\section{Results}

\section{Enrichment of pluripotent stem cells in hASCs}

We determined the mean percentage of $\mathrm{CD}^{+} 4^{+}$and L-NGFR $^{+}$cells in the SVF derived from 8 donors by cytofluorimetric analysis. The mean percentage of $\mathrm{CD} 34^{+}$cells was $13.7 \% \pm 19.5 \%$ and the purity after immunoseparation was $82.6 \% \pm 12.9 \%$ (Fig. 1A). The percentage of $\mathrm{L}-N G F R^{+}$cells was $4.4 \% \pm 6.3 \%$ and the purity of the immunoselected population was $88.5 \% \pm 10.6 \%$ (Fig. 1A).

\section{Phenotype analysis}

The freshly purified L-NGFR ${ }^{+}$and $\mathrm{CD}_{3} 4^{+}$fractions consisted of small round cells rapidly adhering to the plastic and expressing surface markers associated with a primitive phenotype. Despite the high variability among donors, immunomagnetic separation allowed us to identify 2 distinct subpopulations: a high percentage of $\mathrm{L}-N G F R^{+}$cells co-expressed the stem markers CD34 (78\% $\pm 10.6 \%)$, while CD117 and CD105 were variably expressed $(45.9 \% \pm 36.5 \%$

A A FACS Analysis

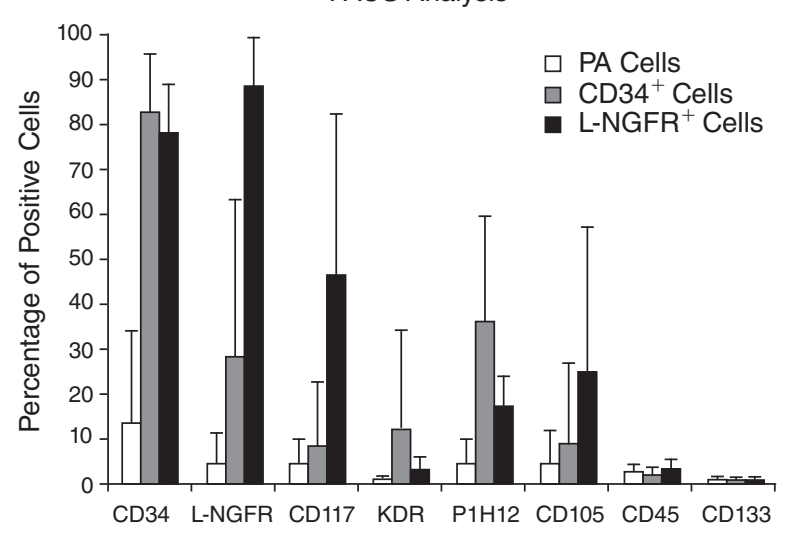

B

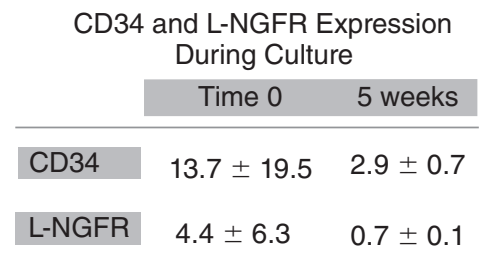

FIG. 1. (A) Immunophenotype of fresh human adiposederived stem cells (hASCs) fractions, analyzed immediately after isolation (PA) or immunoselection $\left(\mathrm{CD} 34^{+}\right.$and $\mathrm{L}_{-N G F R}{ }^{+}$). (B) Modulation of CD34 and low-affinity nerve growth factor receptor (L-NGFR) expression during culture in PA fractions. The $2 \times 10^{5}$ cells were stained with antibodies against specific surface markers and analyzed by FACSCanto II Instrument using DIVA software. Data are expressed as mean percentage $\pm \operatorname{SD}(n=12)$. 
and $24.8 \% \pm 32.3 \%$, respectively). The endothelial-committed progenitor markers KDR and P1H12 were mainly expressed on CD34 ${ }^{+}$cells $(12.2 \% \pm 21.9 \%$ and $36 \% \pm 23 \%$, respectively) (Fig. 1A). Interestingly, CD34 was always highly expressed on L-NGFR ${ }^{+}$cells, whereas a variable but smaller percentage of $\mathrm{CD}^{+} 4^{+}$cells expressed the L-NGFR antigen $(28 \% \pm 34.7 \%)$.

As shown in Figure 1B, both CD34 and L-NGFR expressions were progressively down-modulated during culture and definitively lost within 5-8 weeks.

The $\mathrm{L}-N G F R^{-}$and $\mathrm{CD} 34^{-}$populations were also analyzed. Both fractions showed a strong decrease in stem cell markers expression compared to the positive populations: on CD34- cells (CD34 expression: $0.4 \% \pm 0.5 \%$ ) L-NGFR, KDR, and $\mathrm{P} 1 \mathrm{H} 12$ positivity diminished to $0.97 \% \pm 0.76 \%, 0.64 \% \pm$ $0.79 \%$ and $1.68 \% \pm 1.87 \%$, respectively; on the L-NGFR ${ }^{-}$cells (L-NGFR expression: $0.73 \% \pm 1.1 \%$ ) CD34, CD117, and CD105 decreased to $6.75 \% \pm 1 \%, 7.2 \% \pm 4.5 \%$, and $4.1 \% \pm 3.5 \%$, respectively (Fig. 2A). Flow cytometric analysis of a representative sample is shown in Figure 2B and 2C.

\section{Clonogenic potential}

The clonogenic potential throughout the time of culture was determined in all the 3 populations (Fig. 3). A great variability was found among different donors. At early passages ( $<10$ weeks), we did not observe significant differences among the 3 populations: for $10^{3}$ cells, the CFU-F median number was 254 (range 146-362) in PA cells, 230 (range 132-328) in CD34 cells, and 225 (range 166-285) in L-NGFR ${ }^{+}$cells (Fig. 3A).

At late passages, we observed a decrease in the colony-forming ability in all the 3 populations, particularly in PA hASCs. Indeed, between 10 and 20 weeks, the median number of PA colonies strongly decreased to 37 (range 24-56) and was significantly lower in comparison to L-NGFR ${ }^{+}$cells (CFU-F median number: 118 , range $72-144 ; P=0.04)$, while $\mathrm{CD} 34^{+}$cells median number was 87 (range 56-118) (Fig. 3B). After 20 weeks of culture, PA ability to form colonies nearly disappeared (CFU-F median number: 3 , range 1-5) and was significantly lower in comparison to both $\mathrm{CD}^{+} 4^{+}(52$, range $30-74 ; P=0.04)$ and L-NGFR $^{+}$cells (88, range 30-114; $P=0.03$ ) (Fig. 3C).

\section{Proliferation ability}

To characterize and compare the expansion ability of the different fractions, the cells were maintained in culture until senescence. The expansion rates varied widely among samples from different donors and exhausted within 20-25 weeks of culture. Differences in proliferation ability among the 3 fractions were not statistically significant, but in the long period PA cells showed a marked reduction in their dividing potential in comparison to the immunoseparated cells. In fact, both CD $34^{+}$and L-NGFR ${ }^{+}$ fractions showed high increments in cell proliferation when compared to PA: PA median fold increase (F.I.) was 39.13 (range 27-70), while the median F.I. versus PA (arbitrarily fixed as 1) was 6.04 (range 5.91-26.64) and 21.71 (range 13.22-105.85) for CD34 ${ }^{+}$and L-NGFR ${ }^{+}$cells, respectively $(n=6)$ (Fig. 4A).

Morphologic appearance. At early weeks of culture, all the 3 populations showed the typical fibroblast-like aspect. After 15-20 weeks, the morphological appearance of the 3 fractions became quite different: PA hASCs grew with a larger and flatten shape, with cells gathered in clusters and cytoplasm rich in granules, in contrast to the immunoselected cells that still appeared homogeneous, spindle-shaped, and with well-defined shape and nuclei (Fig. 4B).

\section{Hematopoietic progenitors evaluation}

In order to investigate the presence of hematopoietic progenitors within $\mathrm{CD} 34^{+}$fractions isolated from adipose tissue, hematopoietic culture assays were performed to verify the ability of immunoselected $\mathrm{CD} 4^{+}$cells to form lineagecommitted hematopoietic progenitors, according to their growth in semisolid cultures: CFU-GM and BFU-E.

After 14 days of culture, we never observed hematopoietic progenitors growth in none of the samples analyzed $(n=5)$ : on methylcellulose medium, $\mathrm{CD} 34^{+}$cells always gave rise to a monolayer of cells with fibroblast-like morphology.

\section{Differentiation ability}

Adipogenic differentiation. When grown in adipogenic medium, hASCs from the 3 fractions showed clear-cut differences, as revealed by Oil Red-O staining and quantification (Fig. 5A). CD34 ${ }^{+}$and L-NGFR ${ }^{+}$cells showed significant increments in differentiation ability compared to the PA unselected cells (arbitrarily fixed at 100\%): the average increments were $55 \% \pm 59 \%(P=0.032)$ and $80 \% \pm 86 \%(P=0.031)$ for $\mathrm{CD}_{3} 4^{+}$and $\mathrm{L}_{-N G F R}{ }^{+}$hASCs, respectively $(n=9)$. We analyzed the modulation of the adipogenic differentiation ability of the 3 populations at different periods during culture: Figure 5B shows a representative sample of the adipogenic potential of PA, CD34 ${ }^{+}$, and $\mathrm{L}_{-} \mathrm{NGFR}^{+} \mathrm{hASC}$ isolated from a single donor. At early passages ( $<10$ weeks of culture), the immunoselected populations possessed a greater ability to produce lipid droplets in comparison to PA cells. At later passages ( $>10$ weeks), the adipogenic ability of the immunoselected cells was reduced, even if they still maintained greater levels of lipid vacuoles production compared to the unselected cells.

Osteogenic differentiation. The 3 fractions of hASCs showed even more clear-cut differences in their extracellular calcified matrix deposition, as determined by Alizarin Red $S$ staining and quantification. As shown in Figure 6A, CD34 ${ }^{+}$ and L-NGFR ${ }^{+}$hASCs showed a significant increase in their differentiation ability compared to the PA cells (arbitrarily fixed at $100 \%$ ): the average increment was $+386 \% \pm 288 \%$ $(P=0.0037)$ for CD34 ${ }^{+}$hASCs, and $+338 \% \pm 235 \%(P=$ $0.0024)$ for $\mathrm{L}_{-} \mathrm{NGFR}^{+}$cells $(n=9)$. In addition, this difference between the immunoselected and the PA hASCs populations was maintained in the long term, although the calcified matrix deposition strongly decreased for all of them during culture, as reported in Figure 6B where a representative hASCs sample derived from a single donor is shown. At later passages ( $>10$ weeks), the 2 immunoselected populations behaved quite similarly, maintaining more abundant levels of extracellular calcium depots in comparison to PA cells.

Chondrogenic differentiation assessment. The chondrogenic potential of the $3 \mathrm{hASC}$ populations was evaluated determining GAGs production in cells differentiated in a pellet culture condition. The immunopurified populations showed a 
A

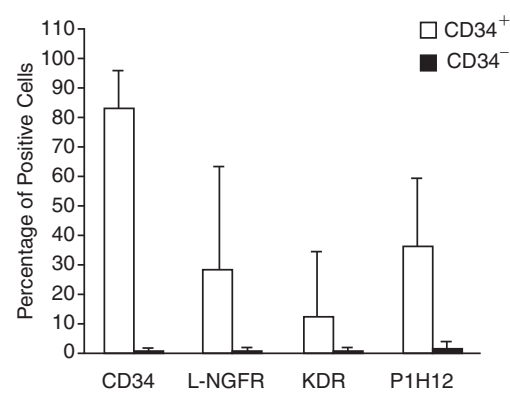

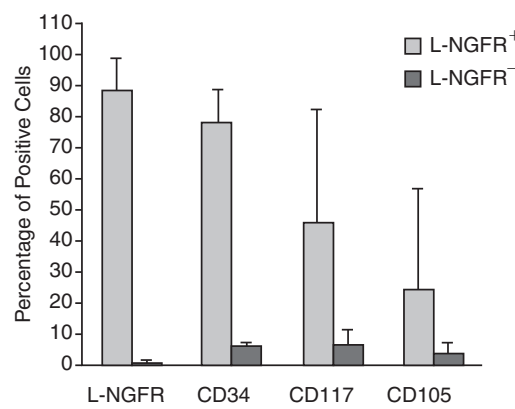

B

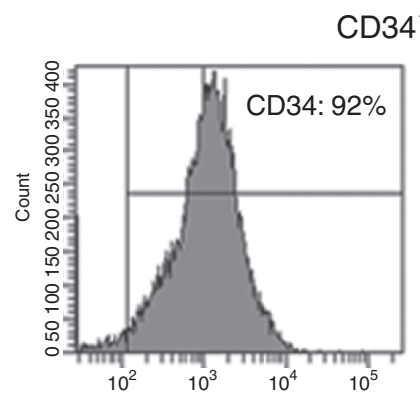

Cells
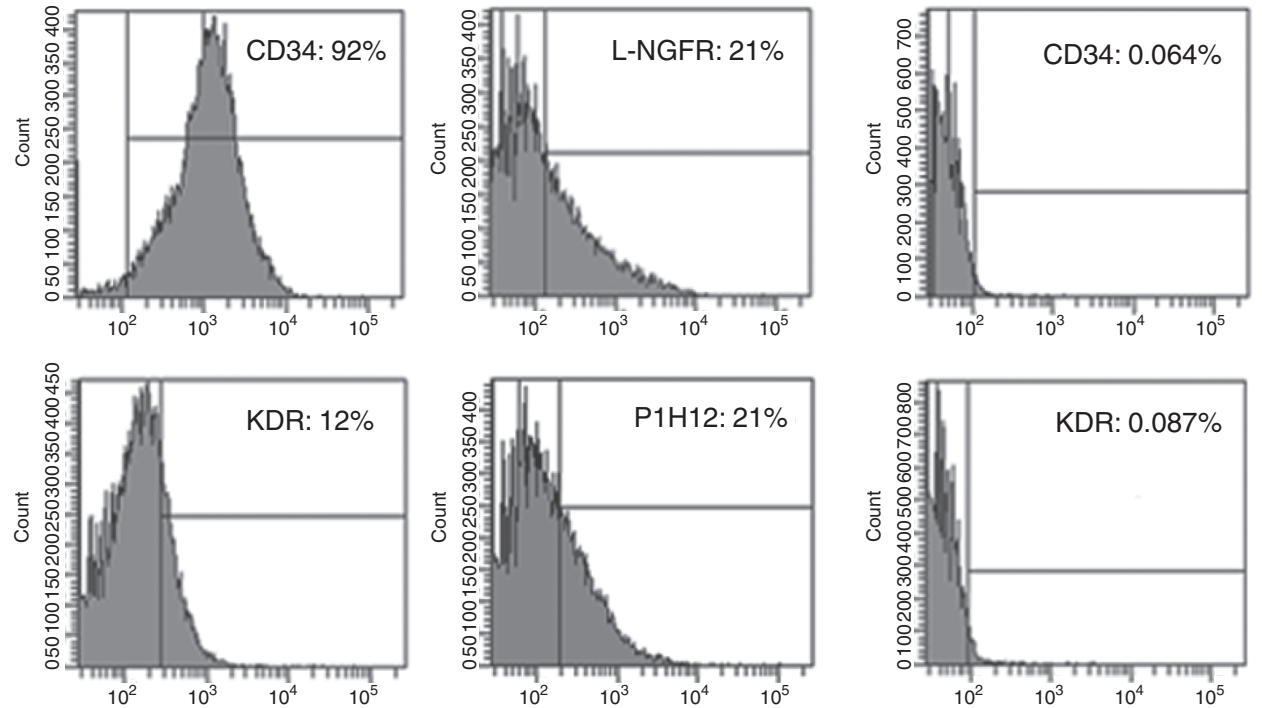

CD34 ${ }^{-}$Cells
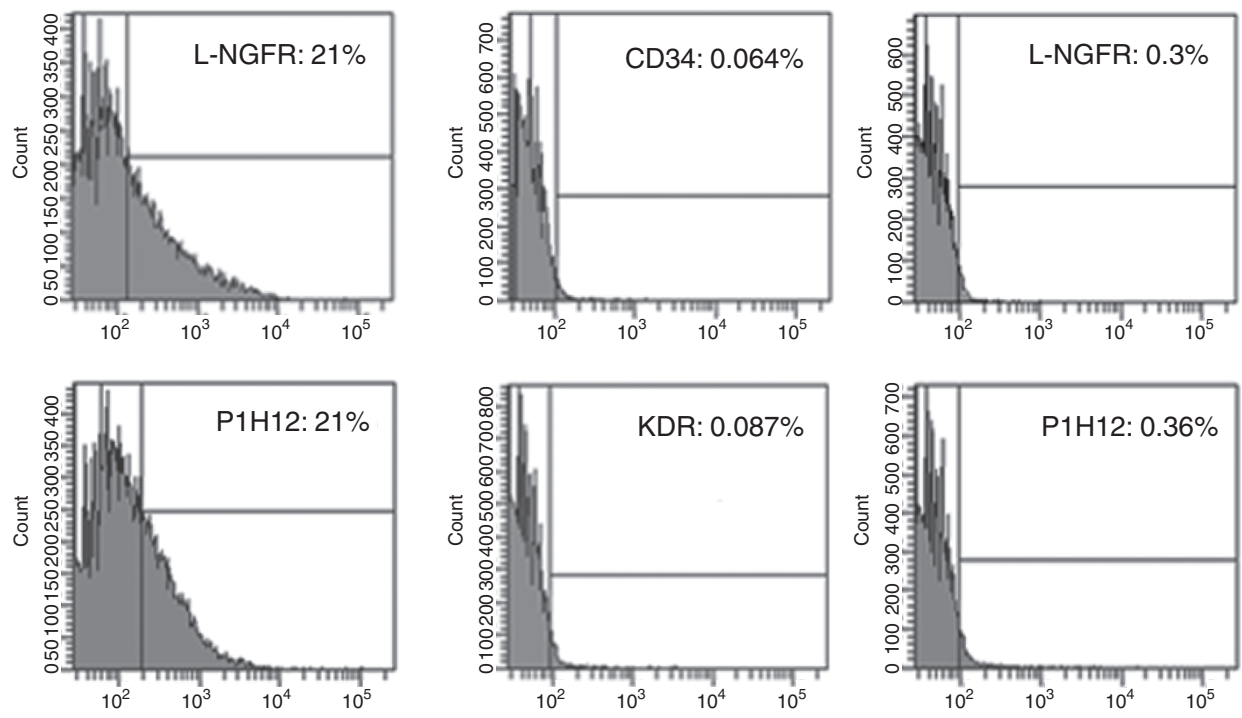

C

L-NGFR ${ }^{+}$Cells
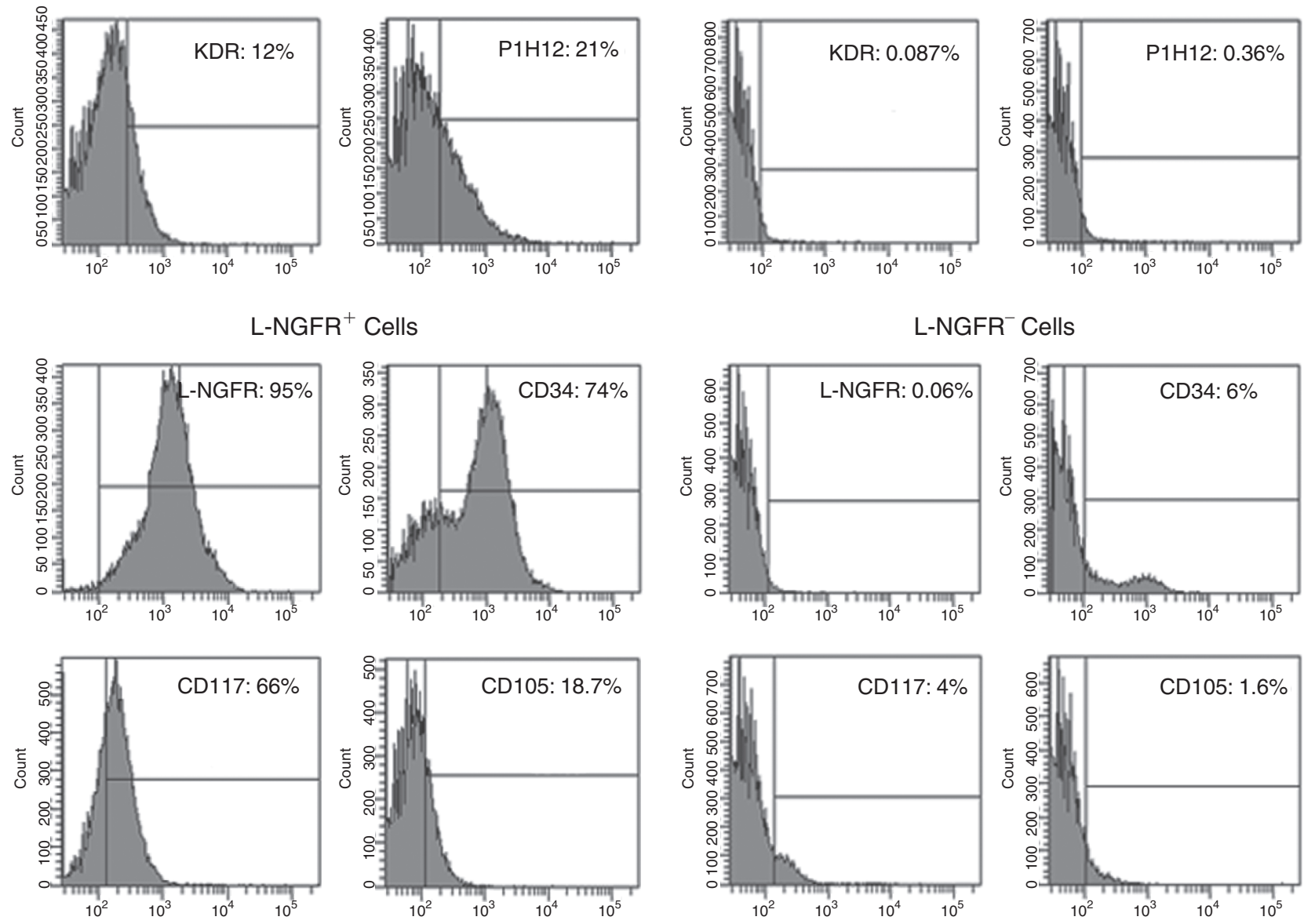

FIG. 2. (A) Surface marker expression in positive and negative CD34 (left panel) and L-NGFR (right panel) fractions. Data are expressed as mean $\pm \mathrm{SD}(n=12)$. (B and C) Flow cytometric analysis of CD34 and L-NGFR positive and negative fractions from a representative sample. The percentages of positive cells are reported in each panel.

similar differentiation potential when compared to PA hASCs, arbitrarily fixed at $100 \%\left(\mathrm{CD} 34^{+}:+2 \% \pm 35 \%\right.$; L-NGFR ${ }^{+}:+22 \%$ $\pm 50 \%)($ Fig. $7 \mathrm{~A})(n=6)$. In Figure 7B, we analyzed GAGs production in the 3 hASCs populations isolated from a single donor and differentiated at different times during culture: at early passages $\left(<10\right.$ weeks) L-NGFR ${ }^{+}$cells produced higher amounts of GAGs in comparison to the other 2 fractions. However at later passages ( $>10$ weeks), we observed a progressive decrease in GAGs production with no relevant differences among the populations. 
A

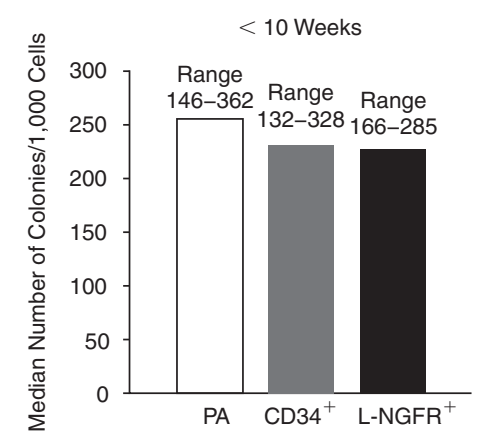

B

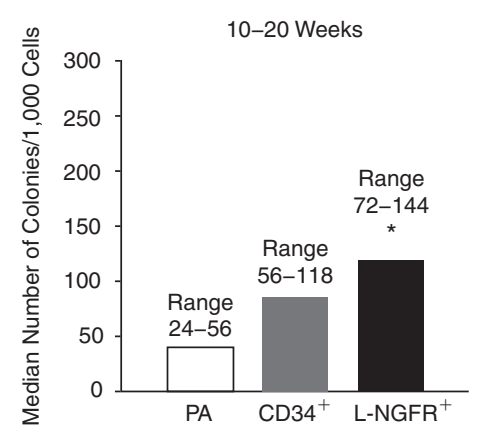

C

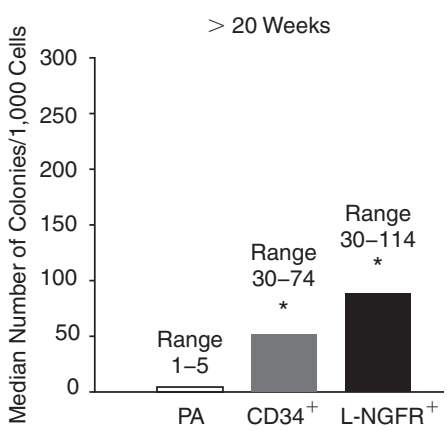

FIG. 3. CFU-F activity of the $3 \mathrm{hASC}$ fractions. Median number of colonies for $1 \times 10^{3}$ cells evaluated at various passages: no significant differences among the 3 populations were observed within 10 weeks of culture (A), while the median number of PA colonies was significantly lower (37) in comparison to L-NGFR ${ }^{+}$cells $(118 ; P=0.04)$ between 10 and 20 weeks of culture $(B)$, and in comparison to both $\mathrm{CD}^{+} 4^{+}(52 ; P=0.043)$ and L-NGFR ${ }^{+}$cells $(88 ; P=0.03)$ after 20 weeks of culture $(\mathbf{C})(n=6)$. ${ }^{*} P<0.05$.

Analyzing the DNA content of each pellet to normalize the GAGs levels, we found that DNA in PA and CD $34^{+}$chondrogenic micromasses was about 2-fold higher compared to pellets cultured in control medium (Fig. 7C), whereas there was no significant difference between differentiated and undifferentiated $\mathrm{L}^{-N G F R}{ }^{+}$micromasses $\left({ }^{*} \mathrm{CD} 34^{+}\right.$chondro versus $\mathrm{CD} 34^{+}$control: $P=0.027$ and ${ }^{*} \mathrm{PA}$ chondro versus PA control: $P=0.034$ ) (Fig. 7C).

Interestingly, a significant difference in GAGs production among the 3 populations was observed in micromasses
A

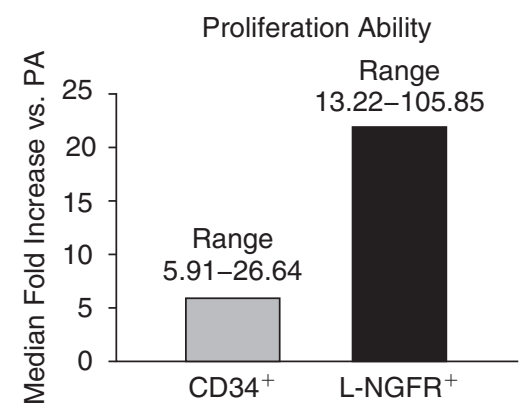

B

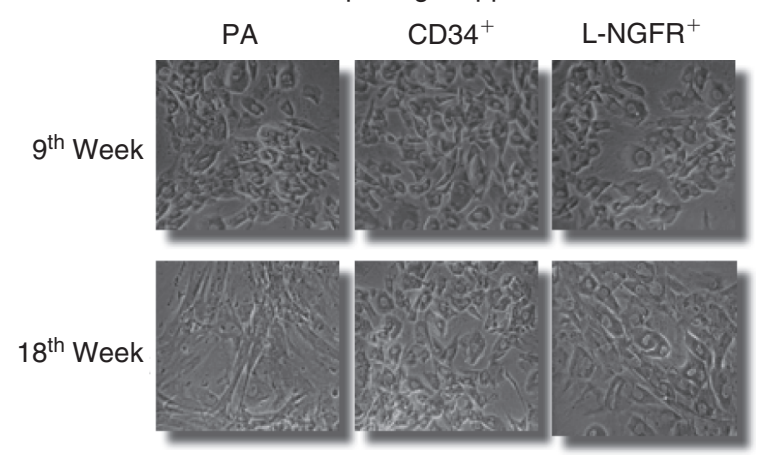

FIG. 4. (A) Proliferation ability of immunoseparated fractions. The median fold increase versus PA was 6.04 and 21.71 for $\mathrm{CD}_{3} 4^{+}$and L-NGFR ${ }^{+}$hASCs, respectively $(n=6)$. The fold increase was calculated as the final absolute number of cells obtained when all of the starting cells expanded to senescence, divided by the starting number of cells, and normalized to PA arbitrarily fixed at 1. (B) Morphologic appearance of PA, CD34 ${ }^{+}$, and L-NGFR ${ }^{+}$cells at 9th week (upper panel) and 18th week (lower panel) of culture (optical microscopy, $400 \times)$ of a female, 38-year-old donor.
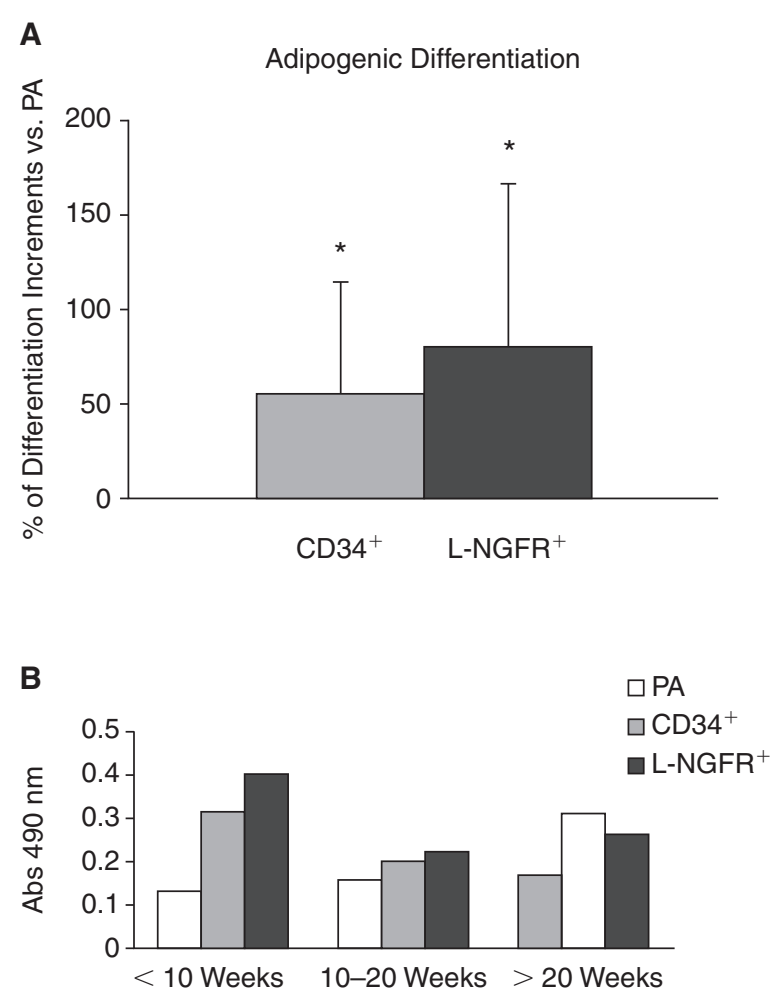

FIG. 5. Assessment of adipogenic differentiation by lipid vacuoles quantification. (A) Mean increments in lipid droplets formation of the immunoselected populations in respect to PA cells during the first 10 weeks of culture (CD34 $4^{+}$: $+55 \% \pm 59 \%,{ }^{*} P=0.017$; $\left.\mathrm{L}^{-N_{G}} \mathrm{FF}^{+}:+80 \% \pm 86 \%,{ }^{*} \mathrm{P}=0.017\right)$ $(n=9)$. (B) Quantification of lipid vacuoles in PA, CD34 ${ }^{+}$, and $\mathrm{L}-N G F R^{+}$cells isolated from a representative donor, adipose-induced after different periods of culture. 
A

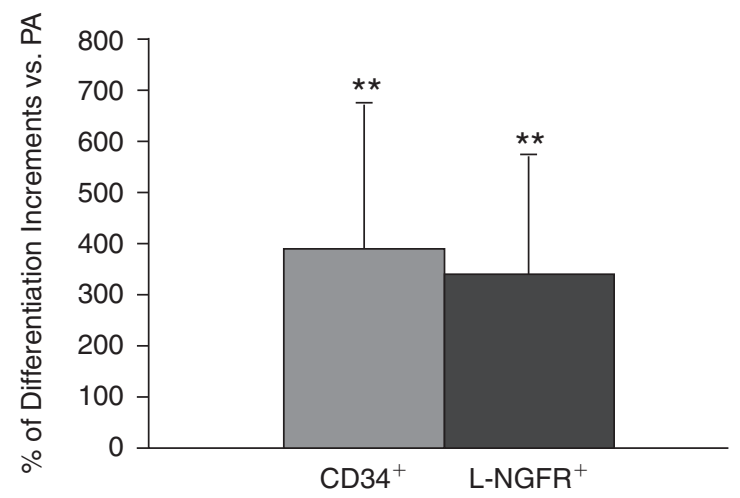

B

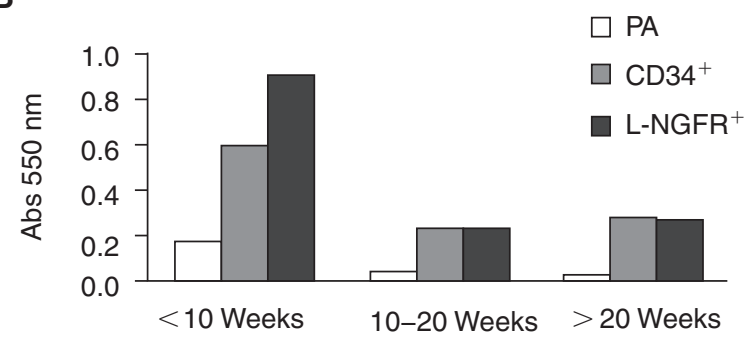

FIG. 6. Evaluation of osteogenic differentiation by calcified extracellular matrix quantification. (A) Mean increments in calcium deposition of $\mathrm{CD}_{3} 4^{+}$and $\mathrm{L}_{-} \mathrm{NGFR}^{+}$cells versus PA during the first 10 weeks of culture $\left(\mathrm{CD} 34^{+}:+386 \% \pm 288 \%\right.$, ${ }^{* * P}=0.0037$; L-NGFR $\left.{ }^{+}:+338 \% \pm 235 \%,{ }^{* *} P=0.0024\right)(n=$ 9). (B) Modulation of calcified extracellular matrix production in $\mathrm{PA}, \mathrm{CD}^{+} 4^{+}$, and $\mathrm{L}_{-} \mathrm{NGFR}^{+}$cells from a representative donor, osteocyte-induced after different period of culture.

cultured in control medium: indeed, undifferentiated CD $34^{+}$ and L-NGFR ${ }^{+}$cells produced higher levels of GAGs with an increase of $+47 \% \pm 32 \%(P=0.007)$ and $+81 \% \pm 90 \%$ $(P=0.038)(n=6)$, respectively, compared to PA undifferentiated micromasses, arbitrarily fixed at 1 (Fig. 7D).

\section{Discussion}

The potential utility of human adipose tissue as a source of adult stem cells for regenerative medical therapies needs more stringent isolation procedures and characterization both to improve the homogeneity of the population and to enhance the reproducibility of the results.

Indeed, adipose tissue is a highly heterogeneous tissue: donor-dependent differences have been demonstrated in cell yield, proliferation, and differentiation ability, most likely influenced by age [30,31-33], sex, hormones, body mass index (BMI) [42,43], inflammatory and pathological conditions like osteoarthritis and diabetes [44,45]. In addition, Jurgens et al. [46] have recently demonstrated that not only differences exist among individuals, but also yield and functional features of hASCs are affected by the adipose tissue-harvesting site.

Despite the extensive characterization, there is still a lack of specific markers and methods to selectively isolate the more primitive cells from adipose tissue.
The results of our study show that the immunomagnetic sorting of hASCs by L-NGFR and CD34 antibodies allows the selection of 2 distinct subpopulations, which are more efficient in clonogenic and differentiative abilities compared to the whole population.

The enrichment of MSCs by a selection with the L-NGFR monoclonal antibody has been previously described in adult BM [34], where it defines a subset of cells with high proliferative, clonogenic, and multipotential differentiation ability. Recently, Yamamoto et al. [47] isolated and analyzed L-NGFR ${ }^{+}$ cells from mouse subcutaneous adipose tissue, showing that the rate of differentiation into adipocytes, osteoblasts, and neuronal cells was higher than for L-NGFR ${ }^{-}$ASCs.

In human adipose tissue, L-NGFR and CD34 MoAbs were able to identify 2 fractions expressing surface markers associated with a primitive phenotype. A high percentage of freshly isolated L-NGFR ${ }^{+}$hASCs expressed the stem cell marker CD34 on the cellular membrane and variable but consistent expressions of CD117 (c-kit, the stem cell factor receptor) and CD105 (SH2). Fresh $\mathrm{CD}^{+}{ }^{+}$cells showed a marked positivity for the endothelial-specific markers $\mathrm{P} 1 \mathrm{H} 12$ and KDR, and variable co-expression of L-NGFR. Although CD34 is the human surface antigen identifying the population of BM hematopoietic stem cells, commonly used as a marker in clinical settings $[48,49]$, in our experiments the lack of expression of the pan-leukocyte marker CD45 and the incapability of hASCs to give rise to hematopoietic colonies under specific stimuli allows us to exclude the hematopoietic origin of $\mathrm{CD} 34^{+}$adipose stem cells. As already reported, Lee et al. [50] isolated a population of muscle-derived CD34 ${ }^{+}$ stem cells able to improve both muscle regeneration and bone healing, whereas Garcia-Pacheco et al. [51] found that human decidual stromal cells positive for both CD34 and STRO-1 are related to BM stromal precursors. Moreover, expression of CD34 had been already reported in BM MSCs, although it was rapidly lost after in vitro culture [34,52,53]. Accordingly, we observed that L-NGFR and CD34 expressions are progressively down-modulated during culture, in parallel with both the reduction of hASCs clonogenic and multi-differentiative ability and the acquisition of a mature fibroblast phenotype. The developmentally programmed loss of marker expression is reminiscent of what was observed in the case of the CD34 [54], L-NGFR [34], and Stro-1 [55] antigens on BM MSCs, supporting the hypothesis that they are markers of primitive cells.

Both immunoseparated cellular fractions showed higher proliferative ability throughout the time of culture compared to PA hASCs. Due to the wide interdonor variability, differences in proliferation among the fractions are not statistically significant, but reflect what previously observed in BM MSCs [34]. In addition, PA cells prematurely showed morphological signs of suffering and senescence.

At early passages, the clonogenic potential of the 3 populations was similar, but a significant difference was observed at later passages, when the immunoseparated fractions longer maintained the ability to form colonies.

Adipogenic differentiation ability of PA hASCs was pronounced throughout the time of culture, probably due to a precommitment of adipose-derived stem cells. However, during the early weeks of culture, adipogenic differentiation was statistically different between selected and unselected cells.

Differences among the 3 fractions are more evident in the osteogenic differentiation: the immunoselected hASCs 
A

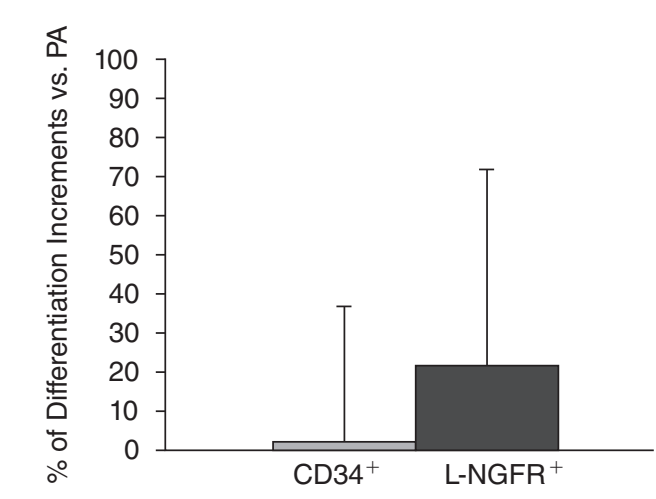

B

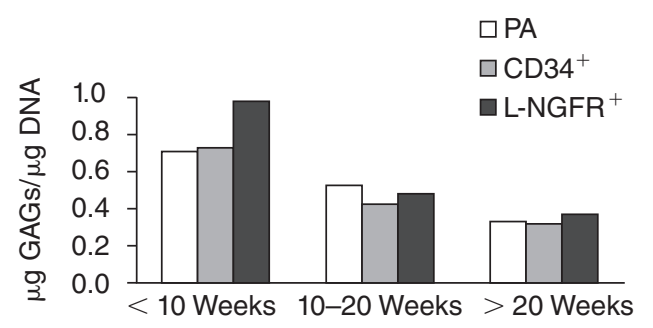

C

\begin{tabular}{l|ccc} 
& PA & CD34 $^{+}$ & L-NGFR $^{+}$ \\
\hline CTRL & $4.40 \pm 1.65$ & $3.53 \pm 1.88$ & $4.39 \pm 2.64$ \\
& & & \\
Chondro & $7.30 \pm 2.56^{*}$ & $8.20 \pm 3.45^{*}$ & $4.38 \pm 1.30$
\end{tabular}

\section{D}

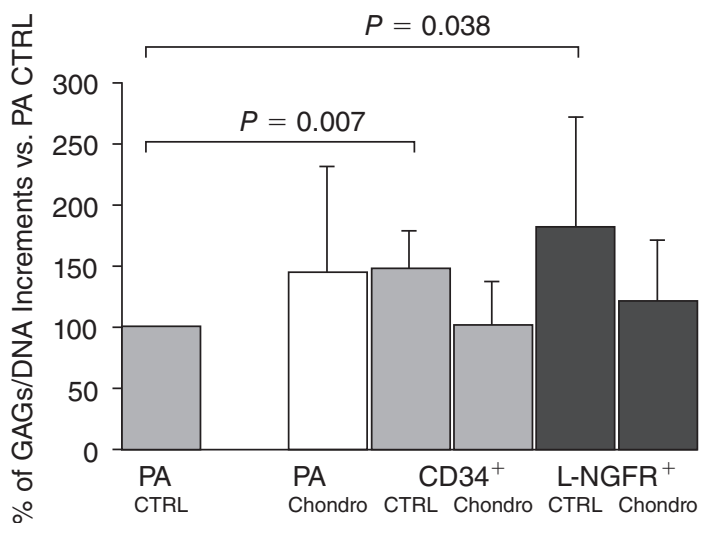

FIG. 7. Assessment of chondrogenic differentiation by glycosaminoglycans (GAGs) quantification. (A) Mean increments in GAGs production of $\mathrm{CD}_{4}{ }^{+}$and L-NGFR ${ }^{+}$cells with respect to PA during the first 10 weeks of culture $\left(\mathrm{CD} 34^{+}:+2 \% \pm 35 \%\right.$; L-NGFR $\left.^{+}:+22 \% \pm 50 \%\right)(n=9)$. (B) Quantification of GAGs in PA, CD34 ${ }^{+}$, and L-NGFR ${ }^{+}$cells from a representative donor, chondro-induced after different period of culture. (C) DNA content in each pellet formed by PA, CD34 ${ }^{+}$, and L-NGFR ${ }^{+}$cells maintained in either control or chondrogenic medium $(n=6)\left({ }^{*} \mathrm{PA}\right.$ chondro versus PA control: $P=0.034 ;{ }^{*} \mathrm{CD} 34^{+}$chondro versus $\mathrm{CD}^{+} 4^{+}$control: $\left.P=0.027\right)$. (D) Increments of GAGs content in pellets cultured either in control or chondrogenic medium with respect to PA pellets maintained in control medium, arbitrarily fixed at $100 \%(n=6)\left(\mathrm{CD} 34^{+}\right.$control versus PA control: $+47 \% \pm 32 \%, P=0.007$; L-NGFR ${ }^{+}$control versus PA control: $\left.+81 \% \pm 90 \%, P=0.038\right)$. In $\mathbf{C}$ and $\mathbf{D}$, data are expressed as mean $\pm \mathrm{SD}$.

showed a clearly higher differentiation ability, particularly during the early passages in culture. Despite a common decrease in calcium deposition during culture, the selected fractions always maintained higher levels than PA hASCs at first passages.

All the populations behaved similarly in term of chondrogenic ability, even if during the first weeks of culture $\mathrm{L}-N G F R^{+}$cells seemed to possess a greater differentiation potential. Nevertheless, the immunoselected subpopulations better responded both to the physical stimuli and to the ipoxia condition of the 3-dimensional culture, positively affecting the chondrogenic differentiation [56]. Indeed, just the $3 \mathrm{D}$ condition induced $\mathrm{CD}_{3}{ }^{+}$and $\mathrm{L}^{-\mathrm{NGFR}^{+}}$cells to produce similar or even higher levels of GAGs than PA hASCs cultured in chondrogenic medium. No differences in GAGs production were observed between $\mathrm{L}-\mathrm{NGFR}^{+}$micromasses cultured in control and in chondrogenic medium: this could be due to the greater ability of the selected hASCs to respond to the 3D physical stimuli that could partially mask the differentiative effect of chondrogenic medium.

Furthermore, DNA quantification showed a higher proliferative effect of the chondrocyte-inductive TGF- $\beta$ on PA and $\mathrm{CD}_{3} 4^{+}$fractions in comparison to $\mathrm{L}-\mathrm{NGFR}^{+}$cells, maybe depending on the greater heterogeneity of these populations, which contain primitive cells able to differentiate, but also cells only able to respond to the proliferative stimuli provided by the growth factor.

Altogether, our data suggest that the selection with antiL-NGFR MoAb allows us to obtain a more homogeneous and primitive population: the almost total co-expression of CD34, the expression of the stem markers CD117 and CD105, and the higher proliferative, clonogenic, and differentiative potential, in particular at early passages, seem to support this observation. The role of L-NGFR in MSCs is still unclear, although its expression has been described in BM and in other tissues [34,57] and it has been shown to be involved in several functions including morphogenesis [58-61], growth factor presentation [62], and apoptosis in response to NGF stimulation [63].

We observed a higher heterogeneity in $\mathrm{CD} 34^{+}$population, with $<30 \%$ of cells co-expressing L-NGFR and low levels of CD117 and CD105 expression. In the last years, some authors isolated from human adipose tissue $\mathrm{CD} 34^{+} / \mathrm{CD} 31^{-}$cells including adipocytes progenitor cells and CD $34^{+} / \mathrm{CD} 31^{+}$cells defined as capillary endothelial cells $[18,64]$. They proposed that adipocytes and endothelial cells might share a common precursor, as also suggested by Planat-Benard et al. [19], which could play a determinant role in the excessive development of the adipose tissue by contributing to neovascularization and to the apparent adipocyte hyperplasia. 
Moreover, Traktuev et al. [65] recently described a hASCs

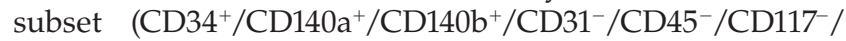
$\mathrm{CD} 144^{-}$) with pericytic properties that participate in vascular stabilization by mutual structural and functional interactions with endothelial cells, maintaining the ability to differentiate into multiple lineages. These evidences suggest that $\mathrm{CD}_{3} 4^{+} \mathrm{hASC}$ could be preferentially used for bone tissue engineering, due to their ability to promote the neovascolarization process, which is known to be a critical point in the healing of bone defects.

These days, in the field of regenerative medicine, physicians prefer one-step surgical procedures in order to reduce patients' discomfort, risks of pathogens transmission, and social costs. In this context, the possibility to rapidly select subpopulations of cells more prone to differentiate into a specific lineage would be very advantageous.

In conclusion, our results suggest that both subpopulations could be useful tools in regenerative medicine applications; nevertheless, best results could be obtained by investigating the interaction between immunoselected hASCs and specific biomaterials, either in a static or in a dynamic culture condition, in order to achieve the most functional cell-scaffold construct.

\section{Acknowledgments}

Authors would like to thank Dr. Franz W. Baruffaldi Preis, Dr. Luciano Lanfranchi, and Dr. Matteo Sartori for their contribution to the work.

\section{Author Disclosure Statement}

No author has proprietary interest or conflict of interests in connection with the present manuscript.

\section{References}

1. Pittenger MF, AM Mackay, SC Beck, RK Jaiswal, R Douglas, JD Mosca, MA Moorman, DW Simonetti, S Craig and DR Masrhak. (1999). Multilineage potential of adult human mesenchymal stem cells. Science 284:143-147.

2. Zvaifler NJ, L Marinova-Mutafchieva, G Adams, CJ Edwards, J Moss, JA Burger and RN Maini. (2000). Mesenchymal precursor cells in the blood of normal individuals. Arthritis Res 2:477-488.

3. Kuznetsov SA, MH Mankani, S Gronthos, K Satomura, P Bianco and PG Robey. (2001). Circulating skeletal stem cells. J Cell Biol 153:1133-1140.

4. Zuk PA, M Zhu, P Ashjian, DA De Ugarte, JI Huang, H Mizuno, ZC Alfonso, JK Fraser, P Benhaim and MH Hedrik. (2002). Human adipose tissue is a source of multipotent stem cells. Mol Biol Cell 13:4279-4295.

5. Erices A, P Conget and JJ Minguell. (2000). Mesenchymal progenitor cells in human umbilical cord blood. Br J Haematol 109:235-242.

6. Goodwin HS, AR Bicknese, SN Chien, BD Bogucki, CO Quinn and DA Wall. (2001). Multilineage differentiation activity by cell isolated from umbilical cord blood: expression of bone, fat, and neural markers. Blood Marrow Transplant 7:581-588.

7. Bieback K, S Kern, H Klueter and H Eichler. (2004). Critical parameters for the isolation of mesenchymal stem cells from umbilical cord blood. Stem Cells 22:625-634.

8. Kogler G, SSensken, JA Airey, T Trapp, M Mueschen, N Feldhan, S Liedtke, RV Sorg, J Fischer, C Rosenbaum, S Greschat, A Knipper, J Bender, O Degistirici, J Gao, AI Caplan, EJ Colletti, G Almeida-
Porada, HW Mueller, E Zanjani and P Wernet. (2004). A new human somatic stem cell from placental cord blood with intrinsic pluripotent differentiation potential. J Exp Med 200:123-135.

9. Jiang Y, B Vaessen, T Lenvik, M Blackstad, M Reyes and CM Verfaille. (2002). Multipotent progenitor cells can be isolated from postnatal murine bone marrow, muscle, and brain. Exp Hematol 30:896-904.

10. In't Anker PS, SA Scherjon, C Kleijburg-van der Keur, WA Noort, FH Claas, R Willemze, WE Fibbe and HH Kanhai. (2003). Amniotic fluid as a novel source of mesenchymal stem cells for therapeutic transplantation. Blood 102:1548-1549.

11. Zuk PA, M Zhu, H Mizuno, J Huang, AJ Katz, P Benhaim, HP Lorenz and MH Hedrick. (2001). Multilineage cells from human adipose tissue: implications for cell-based therapies. Tissue Eng 7:211-228.

12. Halvorsen YD, D Franklin, AL Bond, DC Hitt, C Auchter, AL Boskey, EP Paschalis, WO Wilkison and JM Gimble. (2001). Extracellular matrix mineralization and osteoblast gene expression by human adipose tissue-derived stromal cells. Tissue Eng 7:729-741.

13. Erickson GR, JM Gimble, DM Franklin, HE Rice, H Awad and F Guilak. (2002). Chondrogenic potential of adipose tissue-derived stromal cells in vitro and in vivo. Biochem Biophys Res Commun 290:763-769.

14. Safford KM, KC Hicok, SD Safford, YD Halvorsen, WO Wilkison, JM Gimble and HE Rice. (2002). Neurogenic differentiation of murine and human adipose-derived stromal cells. Biochem Biophys Res Commun 294:371-379.

15. Mizuno H, PA Zuk, M Zhu, HP Lorenz, P Benhaim and MH Hedrick. (2002). Myogenic differentiation by human processed lipoaspirate cells. Plast Reconstr Surg 109:199-209.

16. Ashjian PH, AS Elbarbary, B Edmonds, D DeUgarte, M Zhu, PA Zuk, HP Lorenz, P Benhaim and MH Hedrick. (2003). In vitro differentiation of human processed lipoaspirate cells into early neural progenitors. Plast Reconstr Surg 111:1922-1931.

17. Huang JI, PA Zuk, NF Jones, M Zhu, HP Lorenz, MH Hedrick and P Benhaim. (2004). Chondrogenic potential of multipotential cells from human adipose tissue. Plast Reconstr Surg 113:585-594.

18. Miranville A, C Heeschen, C Sengenes, CA Curat, R Busse and A Bouloumié. (2004). Improvement of postnatal neovascularization by human adipose tissue-derived stem cells. Circulation 110:349-355.

19. Planat-Benard V, JS Silvestre, B Cousin, $M$ Abdré, $M$ Nibbelink, $R$ Tamarat, M Clerque, C Manneville, C Saillan-Barreau, M Duriez, A Tedqui, B Levy, L Pénicaud and L Casteilla. (2004). Plasticity of human adipose lineage cells toward endothelial cells: physiological and therapeutic perspectives. Circulation 109:656-663.

20. Planat-Benard V, C Menard, M Andrè, M Puceat, A Perez, JM Garcia-Verdugo, L Pénicaud and L Casteilla. (2004). Spontaneous cardiomyocyte differentiation from adipose tissue stroma cells. Circ Res 94:223-229.

21. Seo MJ, SY Suh, YC Bae and JS Jung. (2005). Differentiation of human adipose stromal cells into hepatic lineage in vitro and in vivo. Biochem Biophys Res Commun 328:258-264.

22. Puissant B, C Barreau, P Bourin, C Clavel, J Corre, C Bousquet, C Taureau, B Cousin, M Abbal, P Laharrague, L Pénicaud, L Casteilla and A Blancher. (2005). Immunomodulatory effect of human adipose tissue-derived adult stem cells: comparison with bone marrow mesenchymal stem cells. Br J Haematol 129:118-129.

23. McIntosh K, S Zvonic, S Garrett, JB Mitchell, ZE Floyd, L Hammill, A Kloster, Y Di Halvorsen, JP Ting, RW Storms, G Kilroy, X Wu and JM Gimble. (2006). The immunogenicity of human adipose-derived cells: temporal changes in vitro. Stem Cells 24:1246-1253.

24. Gimble JM and F Guilak. (2003). Differentiation potential of adipose derived adult stem (ADAS) cells. Curr Top Dev Biol 58:137-160. 
25. Fraser JK, I Wulur, Z Alfonso and MH Hedrick. (2006). Fat tissue: an underappreciated source of stem cells for biotechnology. Trends Biotechnol 24:150-154.

26. Yoshimura K, K Sato, N Aoi, M Kurita, T Hirohi and K Harii. (2008). Cell-assisted lipotransfer for cosmetic breast augmentation: supportive use of adipose-derived stem/stromal cells. Aesth Plast Surg 32:48-55.

27. Yoshimura K, K Sato, N Aoi, M Kurita, K Inoue, H Suga, H Eto, H Kato, T Hirohi and K Harii. (2008). Cell-assisted lipotransfer for facial lipoatrophy: efficacy of clinical use of adipose-derived stem cells. Dermatol Surg 34:1178-1185.

28. Garcia-Olmo D, M García-Arranz, D Herreros, I Pascual, C Peiro and JA Rodriguez-Montes. (2005). A phase I clinical trial of the treatment of Crohn's fistula by adipose mesenchymal stem cell transplantation. Dis Colon Rectum 48:1416-1423.

29. Garcia-Olmo D, D Herreros, I Pascual, JA Pascual, E Del-Valle, J Zorrilla, P De-La-Quintana, M Garcia-Arranz and M Pascual. (2009). Expanded adipose-derived stem cells for the treatment of complex perianal fistula: a phase II clinical trial. Dis Colon Rectum 52:79-86.

30. Schipper BM, KG Marra, W Zhang, AD Donnenberg and JP Rubin. (2008). Regional anatomic and age effects on cell function of human adipose-derived stem cells. Ann Plast Surg 60:538-544.

31. Van Harmelen V, K Rohrig and H Hauner. (2004). Comparison of proliferation and differentiation capacity of human adipose precursor cells from the omental and subcutaneous adipose tissue depot of obese subjects. Metabolism 53:632-637.

32. Sen A, YR Lea-Currie, D Sujkowska, DM Franklin, WO Wilkison, YD Halvorsen and JM Gimble. (2001). Adipogenic potential of human adipose derived stromal cells from multiple donors is heterogeneous. J Cell Biochem 81:312-319.

33. de Girolamo L, S Lopa, E Arrigoni, MF Sartori, FW Preis and AT Brini. (2009). Human adipose-derived stem cells isolated from young and elderly women: study on their differentiation potential and scaffold interaction during in vitro osteoblastic differentiation. Cytotherapy 11:793-803.

34. Quirici N, D Soligo, P Bossolasco, F Servida, C Lumini and G Lambertenghi Delililers. (2002). Isolation of bone marrow mesenchymal stem cells by anti-nerve growth factor receptor antibodies. Exp Hematol 30:783-791.

35. Gronthos S, DM Franklin, HA Leddy, PG Robey, RW Storms and JM Gimble. (2001). Surface protein characterization of human adipose tissue-derived stromal cells. J Cell Physiol 189:54-63.

36. Mitchell JB, K McIntosh, S Zvonic, S Garrett, ZE Floyd, A Kloster, Y Di Halvorsen, RW Storms, B Goh, G Kilroy, X Wu and JM Gimble. (2006). Immunophenotype of human adiposederived cells: temporal changes in stromal-associated and stem cell-associated markers. Stem Cells 24:376-385.

37. Castro-Malaspina H, RE Gay, G Resnick, N Kapoor, P Meyers, D Chiarieri, S McKenzie, HE Brozmeyer and MA Moore. (1980). Characterization of human bone marrow fibroblast colonyforming cells (CFU-F) and their progeny. Blood 56:289-301.

38. DiGirolamo CM, D Stokes, D Colter, DG Phinney, R Class and DJ Prockop. (1999). Propagation and senescence of human marrow stromal cells in culture: a simple colony-forming assay identifies samples with the greatest potential to propagate and differentiate. Br J Hematol 107:275-281.

39. Stanford CM, PA Jacobson, ED Eanes, LA Lembke and RJ Midura. (1995). Rapidly forming apoptotic mineral in an osteoblastic cell line (UMR 106-01 BSP). J Biol Chem 270:9420-9428.

40. Guilak F, KE Lott, HA Awad, Q Cao, KC Hicok, B Fermor and JM Gimble. (2006). Clonal analysis of the differentiation potential of human adipose-derived adult stem cells. J Cell Physiol 206:229-237.

41. Barbosa I, S Garcia, V Barbier-Chassefière, JP Caruelle, I Martelly and D Papy-Garcia. (2003). Improved and simple micro assay for sulfated glycosaminoglycans quantification in biological extracts and its use in skin and muscle tissue studies. Glycobiology 13:647-653.
42. Jaiswal N, SE Haynesworth, AI Caplan and SP Bruder. (1997). Osteogenic differentiation of purified, culture-expanded human mesenchymal stem cells in vitro. J Cell Biochem 64:295-312.

43. Aust L, B Devlin, SJ Foster, YD Halvorsen, K Hicok, T du Laney, A Sen, GD Willingmyre and JM Gimble. (2004). Yield of human adipose-derived adult stem cells from liposuction aspirates. Cytotherapy 6:7-14.

44. Murphy JM, K Dixon, S Beck, D Fabian, A Feldman and F Barry. (2002). Reduced chondrogenic and adipogenic activity of mesenchymal stem cells from patients with advanced osteoarthritis. Arthritis Rheum 46:704-713.

45. Barry FP. (2003). Biology and clinical applications of mesenchymal stem cells. Birth Defects Res C Embryo Today 69:250-256.

46. Jurgens WJ, MJ Oedayrajsingh-Varma, MN Helder, B Zandiehdoulabi, TE Schouten, DJ Kuik, MJ Ritt and FJ van Milligen. (2008). Effect of tissue-harvesting site on yield of stem cells derived from adipose tissue: implications for cell-based therapies. Cell Tissue Res 332:415-426.

47. Yamamoto N, H Akamatsu, S Hasegawa, T Yamada, S Nakata, MOhkuma, E Miyachi, T Marunouchi and K Matsunaga. (2007). Isolation of multipotent stem cells from mouse adipose tissue. J Dermatol Sci 48:43-52.

48. Murray L, B Chen, A Galy, S Chen, R Tushinki, N Uchida, R Negrin, G Tricot, S Jagannath and D Vesole. (1995). Enrichment of human hematopoietic stem cell activity in the CD34+Thy1+Lin- subpopulation from mobilized peripheral blood. Blood 85:368-378.

49. Menichella G, M Lai, R Serafini, L Pierelli, M Vittori, M Ciarli, C Rumi, P Puggioni, G Scambia, S Sica and G Leone. (1999). Large volume leukapheresis for collecting hematopoietic progenitors: role of CD34+ precount in predicting successful collection. Int J Artif Organ 22:334-341.

50. Lee JY, Z Qu-Petersen, B Cao, S Kimura, R Jankowski, J Cummins, A Usas, C Gates, P Robbins, A Weernig and J Huard. (2000). Clonal isolation of muscle-derived cells capable of enhancing muscle regeneration and bone healing. J Cell Biol 150:1085-1100.

51. Garcia-Pacheco JM, C Oliver, M Kimatrai, FJ Bianco and EG Olivares. (2001). Human decidual stromal cells express CD34 and Stro- 1 and are related to bone marrow stromal precursors. Mol Hum Reprod 7:1151-1157.

52. Deans RJ and AB Moseley. (2000). Mesenchymal stem cells: biology and potential clinical uses. Exp Hematol 28:875-884.

53. Simmons PJ and B Torok-Storb. (1991). CD34 expression by stromal precursors in normal adult bone marrow. Blood 78:2848-2853.

54. Civin CJ, ML Banquerigo, LC Strauss and MR Loken. (1987). Antigenic analysis of hematopoiesis. IV. Flow cytometric characterization of My-10-positive progenitor cells in normal human bone marrow. Exp Hematol 15:10-17.

55. Simmons PJ and B Torok-Storb. (1991). Identification of stromal cell precursors in human bone marrow by a novel monoclonal antibody, STRO-1. Blood 78:55-62.

56. Vinatier C, D Mrugala, C Jorgensen, J Guicheux and D Noel. (2009). Cartilage engineering: a crucial combination of cells, biomaterials and biofactors. Trends Biotechnol 27:307-314.

57. Jones EA, A English, K Henshaw, SE Kinsey, AF Markham, P Emery and D McGonagle. (2004). Enumeration and phenotypic characterization of synovial fluid multipotential mesenchymal progenitor cells in inflammatory and degenerative arthritis. Arthritis Rheum 50(3):817-827.

58. Sariola H, M Saarma, K Sainio, U Arumäe, J Palgi, A Vaahtokari, I Thesleff and A Karavanov. (1991). Dependence of kidney morphogenesis on the expression of nerve growth factor receptor. Science 254:571-573.

59. Lee KF, E Li, LJ Huber, SC Landis, AH Sharpe, MV Chao and R Jaenish. (1992). Targeted mutation of the gene encoding the low affinity NGF receptor $\mathrm{p} 75$ leads to deficits in the peripheral sensory nervous system. Cell 69:737-749. 
60. Campagnolo L, MA Russo, A Puglianiello, A Favale and G Siracusa. (2001). Mesenchymal cell precursors of peritubular smooth muscle cells of the mouse testis can be identified by the presence of the p75 neurotrophin receptor. Biol Reprod 64:464-472.

61. Suzuki K, M Tanaka, N Watanabe, S Saito, H Nonaka and A Miyajima. (2008). p75 Neurotrophin receptor is a marker for precursors of stellate cells and portal fibroblasts in mouse fetal liver. Gastroenterology 135:270-281.

62. Glass DJ, SH Nye, P Hantzopoulos, MJ Macchi, SP Squinto, M Goldfarb and GD Yancopoulos. (1991). TrкB mediates BDNF/ NT-3-dependent survival and proliferation in fibroblast lacking the low affinity NGF-receptor. Cell 66:405-413.

63. Trim N, S Morgan, M Evans, R Issa, D Fine, S Afford, B Wilkins and J Iredale. (2000). Hepatic stellate cells express the low affinity nerve growth factor receptor p75 and undergo apoptosis in response to nerve growth factor stimulation. Am J Pathol 156:1235-1243.

64. Sengenes C, K Lolmede, A Zakaroff-Girard, R Busse and A Bouloumié. (2005). Preadipocytes in the human subcutaneous adipose tissue display distinct features from the adult mesenchymal and hematopoietic stem cells. J Cell Physiol 205:114-122.
65. Traktuev DO, S Merfeld-Clauss, J Li, M Kolonin, W Arap, R Pasqualini, BH Johnstone and KL March. (2008). A population of multipotent CD34-positive adipose stromal cells share pericyte and mesenchymal surface markers, reside in a periendothelial location, and stabilize endothelial networks. Circ Res 102:77-85.

$$
\begin{array}{r}
\text { Address correspondence to: } \\
\text { Dr. Nadia Quirici } \\
\text { Department of Medical Pharmacology } \\
\text { Fondazione Matarelli } \\
\text { Università degli Studi di Milano } \\
\text { Via Vanvitelli, } 32 \\
\text { Milano 20129 } \\
\text { Italy }
\end{array}
$$

E-mail: nadiaquirici@fastwebnet.it

Received for publication October 16, 2009 Accepted after revision November 20, 2009 Prepublished on Lierbert Instant Online November 23, 2009 